Teologia Praktyczna 20(2019)

doi: $10.14746 /$ tp.2019.20.12

ORCID: 0000-0002-8750-3035

\title{
Stewardship. Włodarstwo w Kościele katolickim w Stanach Zjednoczonych Ameryki Północnej (Część 1)
}

\begin{abstract}
„Jako chrześcijańscy włodarze z wdzięcznością przyjmujemy Boże dary, odpowiedzialnie je rozwijamy, z miłością

i w sprawiedliwości dzielimy się nimi z innymi, a pomnożone zwracamy Panu"1.
\end{abstract}

Zawsze nurtowała mnie, jako profesora ekonomii, potrzeba rozwoju nowoczesnej, katolickiej teorii ekonomii, zarządzania i finansów. Koncepcja chrześcijańskiego włodarzowania (stewarship), ogłoszona blisko 60 lat temu przez amerykański episkopat, jest umotywowaną biblijnie i wypływającą z nauczania Kościoła teorią ekonomii, finansowania i zarządzania na poziomie parafii i diecezji. Istota jej polega na włączeniu w życie Kościoła tysięcy wolontariuszy owianych koncepcją włodarstwa w winnicy Pańskiej, którą jest Kościół. Oczywiście aparat pojęciowy, podstawy metodyczne i środowisko prawne ekonomii „laickiej” i „kościelnej” są zbieżne, natomiast ich motywy i cele są różne. Motywy funkcjonowania gospodarki w sensie katolickim wywodzą się z decyzji Wszechmogącego Boga o powierzeniu ludzkości wszechświata, który On stworzył (Rdz 1,26-31), i z przypowieści Jezusa Chrystusa o talentach (Mt. 14-36). Motywy katolickiego włodarzowania dotyczą więc osób, które dobrowolnie się $\mathrm{z}$ tymi motywami identyfikują na poziomie parafii i diecezji

${ }^{1}$ United States Conference of Catholic Bishops. Stewardship A Disciple's Response (2002): A pastoral Letter on Stewardship s. 42. Washington DC. 
oraz państwa. Obecnie koncepcja włodarzowania coraz bardziej przenika do Kościoła powszechnego, czego potwierdzeniem jest encyklika Ojca Świętego Franciszka Laudato si (W trosce o nasz wspólny dom), ogłoszona 18.06.2015 roku, w której dostrzega się wielokrotnie jej zbieżność z Listem pasterskim Konferencji Katolickich Biskupów Stanów Zjednoczonych (USCCB).

Kościół katolicki w świetle świeckiej nauki o zarządzaniu jest olbrzymią, wielostrukturalną i wieloszczeblową organizacją wymagającą sprawnego zarządzania i armii wysokiej klasy fachowców, którzy nim sprawnie pokierują. Wprawdzie Pan nasz, Jezus Chrystus, dał nam niejako gwarancję trwania jego Kościoła na wieki, wypowiadając do Piotra następujące słowa: „Ty jesteś Piotr [czyli Skała], i na tej Skale zbuduję Kościół mój, a bramy piekielne go nie przemogą” (Mt 16,18), ale z drugiej strony, Pan Jezus rzekł: „Żniwo wprawdzie wielkie, ale robotników mało. Proście Pana żniwa, żeby wyprawił robotników na swoje żniwo" (Mt 9,37-38). Odpowiedzialność za obfite żniwa spada na żniwiarzy. Nauka o zarządzaniu dotyczy bardzo wielu aspektów. W szczególności niezmiernie trudne jest zarządzanie zespołami ludzkimi. Parafia - to zespół osób obejmujący zazwyczaj ponad 1000, ale nierzadko nawet do 10000 wiernych. Tej skali przedsiębiorstwa gospodarcze są zaliczane do wielkich organizacji. To porównanie uświadamia wielkość wyzwań, które piętrzą się przed rządcami parafii i diecezji.

Niniejsze opracowanie ma na celu zapoznanie polskiego czytelnika z koncepcją włodarzowania i składa się z dwóch części. Pierwsza część to studium przypadku ukazujące funkcjonowanie systemu włodarzowania w Katolickiej Społeczności Królowej Pokoju w Gainesville Fl, a druga - to studium literaturowe, przedstawiające stan rozwoju koncepcji włodarstwa w Kościele katolickim Stanów Zjednoczonych.

\section{Część 1.}

Studium przypadku - system totalnego wlodarzowania w Katolickiej Społeczności Królowej Pokoju w Gainesville Fl

\section{I. „Macie oczy, a nie widzicie” (Mk 8,18)}

Przez drugą połowę 2017 roku oraz na przełomie lat 2018 i 2019 (łącznie przez 9 miesięcy) wraz z żoną byliśmy rezydentami 250-tysięcznego miasta Gainesville, leżącego w północno-środkowej części Florydy. Z pięciu funkcjonujących w tym mieście parafii Kościoła katolickiego zupełnie losowo, za pomocą Internetu, wybraliśmy kościół katolicki Królowej Pokoju (Queen 
of Peace Catholic Church) jako naszą parafię na okres pobytu na Florydzie. To, co w tej parafii widzieliśmy i przeżywaliśmy, zaskakiwało nas nieustannie $i$ to niezmiernie pozytywnie, od pierwszego do ostatniego dnia naszego pobytu. Marzeniem naszym stało się to, aby wiele z zauważonego i otrzymanego tam dobra przenieść do Polski, a w szczególności do naszej, i tak już bardzo żywotnej, parafii pw. św. Antoniego Padewskiego w Przeźmierowie.

Tymczasem, w czasie pobytu na Florydzie i długo po powrocie do Polski zupełnie nie byliśmy świadomi, że uczestnicząc w życiu tej parafii, mimo woli, zanurzeni zostaliśmy w rozwijanej już od ponad 55 lat w Kościele amerykańskim koncepcji włodarstwa (ang. stewardship). Koncepcja ta została sprecyzowana w 1992 roku w Liście pasterskim dotyczącym włodarstwa (A Pastoral Letter on Stewardship) przez Konferencję Katolickich Biskupów Stanów Zjednoczonych (United States Conference of Catholic Bishops) - (USCCB 2002). Ze względu na bezdyskusyjne znaczenie tej koncepcji w Kościele katolickim w USA oraz ze względu na jej dynamiczny rozwój, konieczne i pilne jest przybliżenie tej koncepcji polskim katolikom, którzy mogą wiele z niej skorzystać zarówno dla dobra osobistego rozwoju duchowego, jak i ku pożytkowi całego Kościoła w Polsce.

Polski Kościół wypracowuje własny model zarządzania parafią, czego wyrazem jest opublikowana broszura pt. Diakonijny model parafialnej Rady Duszpasterskiej jako fundament wspólnoty parafialnej (2014), który jest rodzimą wersją teorii zarządzania na poziomie rady parafialnej. Obydwa wspomniane wyżej dokumenty zostały napisane w trosce o dalszy rozwój Kościoła, i pomimo że nie są one tożsame, to zawierają wzajemnie ubogacające się treści, choć bezstronnie należy stwierdzić, że koncepcja włodarstwa Kościoła USA jest bardzo zaawansowana. Niniejsze opracowanie nie jest analizą porównawczą tych dwóch koncepcji. Amerykańska koncepcja włodarstwa jest realizowana na czterech płaszczyznach: osobistej, parafialnej, diecezjalnej i uniwersalnej (międzynarodowej), sieciowo ze sobą połączonych w celu zwiększenia jej „ewangelizacyjnej efektywności”. Koncepcja włodarzowania jest więc katolicką teorią zarządzania darami, które każdy człowiek otrzymuje „za darmo” od Pan Boga. Darami tymi są: czas, talenty i dobra materialne (time, talents and treasure), które włodarz z wdzięcznością przyjmuje, pomnaża i sprawiedliwie dzieli się nimi z innymi, a pomnożone dary zwraca Panu. Włodarze (stewardzi) są to więc ci katolicy, którzy są umotywowani atrakcyjną wizją stylu życia jako pracowników winnicy Pańskiej.

Struktura artykułu odpowiada procesowi stopniowego odkrywania i poznawania przez nas koncepcji włodarzowania. Pierwsza część artykułu została napisana w konwencji ekscytującego studium przypadku (case study), jakim było niezamierzone, choć nieuniknione poznawanie funkcjonowania tej koncepcji w Katolickiej Społeczności Królowej Pokoju (Queen of Peace Catholic 
Community) w Gainesville na Florydzie. W naszym przypadku było to niejako „odkrywanie odkrytego”, czyli tego, co dla nas było zupełną nowością („Macie oczy, a nie widzicie; macie uszy, a nie słyszycie” - Mk 8,18), a co dla zaangażowanych katolików w USA jest od dawna oczywiste. Druga część artykułu jest już napisana jako studium literaturowe na podstawie źródłowych dokumentów powstałych wyłącznie w Kościele USA.

Omawiając koncepcję włodarzowania w amerykańskim Kościele, uznałem za niezbędne przedstawienie ogromu zadań, które ma do zrealizowania zarówno lokalny Kościół na Florydzie, jak i cały Kościół w USA. Przecież to Pan Jezus rzekł kiedyś do swych uczniów: „Żniwo wprawdzie wielkie, ale robotników mało. Proście Pana żniwa, żeby wyprawił robotników na swoje żniwo" (Mt 9,37-38.) Włodarze amerykańscy są właśnie takimi robotnikami posyłanymi na wielkie żniwo.

\section{Rola Kościoła katolickiego w życiu społecznym Florydy}

Kiedy wybierałem się na Florydę, rysował mi się mglisty obraz Kościoła katolickiego w USA. Był to raczej obraz liberalnego Kościoła w odwrocie, wstrząsanego skandalami. Obraz ten dałem sobie „wmówić” przez niechętne Kościołowi środowiska dziennikarskie. Środowiska te z lubością i bez ustanku wysyłają na cały świat informacje o skandalach w Kościele amerykańskim, a spuszczają zasłonę milczenia na godne najlepszych ocen jego osiągnięcia. W tej szkodliwej dezinformacyjnej polityce upatruję przyczynę tego, że nie miałem żadnej wiedzy o potężnym i ożywczym ruchu włodarstwa (stewardship) funkcjonującym w Kościele USA. Obserwując na żywo nadzwyczaj prężnie rozwijającą się społeczność Queen of Peace Catholic Church w Gainesville, uznałem ją więc za swego rodzaju chlubny i godny naśladowania wyjątek.

Tymczasem religijna społeczna i ekonomiczna rola Kościoła katolickiego na Florydzie, jak wskazują przytoczone poniżej dane statystyczne, jest bardzo istotna. Dlatego wymaga on sprawnego i efektywnego zarządzania w celu wypełnienia jego wizji i misji. Do wypełnienia tej misji Kościół potrzebuje zastępów zaangażowanych osób świeckich. Wizję roli tego partykularnego Kościoła Konferencja Biskupów Katolickich Florydy (Florida Conference of Catholic Bishops) sformułowała w sposób następujący:

Ewangelia Jezusa Chrystusa i nauczanie jego Kościoła kierują pracami Konferencji Katolickich Biskupów Florydy, która poprzez współpracę z przedstawicielami i agencjami rządu Florydy, analizę moralnego wymiaru polityki publicznej, głoszenie świętości życia i godności osoby ludzkiej, prowadzi podejmujących decy- 
zje do uzyskana sprawiedliwych rozwiązań oraz stwarza szanse katolikom z Florydy do wypełniania ich odpowiedzialności za uczestnictwo w życiu politycznym (Florida Conference of Catholic Bishops 2018).

Wizję tę osadzimy w realiach ekonomiczno-społecznych tego stanu. Floryda została odkryta już za czasów Kolumba w 1513 roku, a jej nazwa pochodzi z języka hiszpańskiego i oznacza krainę kwiatów. Została ona kupiona przez rząd USA od Hiszpanii w 1819 roku i już wkrótce, bo w 1845 roku, stała się 27 ich stanem. Stan ten jest położony na południowym wschodzie USA, głównie na półwyspie Floryda, oraz na pasie ziemi o szerokości od 60 do $100 \mathrm{~km}$ i długości $450 \mathrm{~km}$, rozciągającym się w większości wzdłuż północno-wschodniego wybrzeża Zatoki Meksykańskiej, od miasta Pensakola na zachodzie, aż do Jacksonville na Wybrzeżu Atlantyckim na wschodzie, na szerokości geograficznej odpowiadającej środkowemu i południowemu Egiptowi. Od wschodu Florydę oblewają wody Atlantyku, a od zachodu wody Zatoki Meksykańskiej.

Terytorium Polski jest 2,3 razy większe niż Florydy. Obecnie zamieszkuje ją $21 \mathrm{mln}$ ludzi. Na przestrzeni ostatnich siedmiu lat liczba ludności tego stanu zwiększyła się prawie o $2 \mathrm{mln}$, czyli powiększała się o 700 osób dziennie. 14,7\% ludności Florydy żyje w ubóstwie, co jest wskaźnikiem nieco wyższym niż średnia w USA. Granica ubóstwa jest podawana stosownie do wysokości rocznego przychodu w dolarach na rodzinę, w zależności od liczby osób w rodzinie. Dla rodziny składającej się z dwóch osób dorosłych i dwojga dzieci próg ubóstwa w 2018 roku określono na 24858 USD. Oznacza to, że Floryda jest obszarem, gdzie istnieje wielka potrzeba pracy charytatywnej.

Drugim wielkim wyzwaniem dla tego Kościoła jest konieczność integracji mieszkańców Florydy pochodzących niemalże z całego świata. Prawie 20\% społeczeństwa Florydy urodziło się poza Stanami Zjednoczonymi. Urząd Statystyczny USA (US Census Burau) podaje następującą strukturę rasową i etnograficzną tego stanu: biali - 77,6\% (w tym wyłącznie biali - 54,9\%, a Latynosi i osoby pochodzenia hiszpańskiego - 24,9\%), czarni i Afroamerykanie - 16,8\%, Indianie - 0,5\%, Azjaci - 2,9\%, dwu- i więcejrasowi - 2,1\%. Językiem angielskim posługuje się 75\% populacji, a hiszpańskim niemal 19\%; $48 \%$ ludności to protestanci, głównie baptyści. Katolicyzm wyznaje tu 22,6\% ludności, judaizm - 3\%, prawosławie i islam po $1 \%$, a bezwyznaniowcy stanowią $16 \%$.

Statystyka podawana przez Konferencję Katolickich Biskupów Florydy wskazuje, że zamieszkuje ją prawie 2 mln katolików, natomiast rządowe Census Bureau podaje ich liczbę w wysokości 4,4 mln. Różnica 2,4 mln wiernych nie jest błędem i wynika $\mathrm{z}$ metody określania, kto jest katolikiem. W spisie urzędowym do katolików zalicza się nawet tych wszystkich, którzy deklarują się, że są katolikami, nie mając żadnego związku z Kościołem. Kościół hierar- 
chiczny to 2 arcybiskupów, 11 biskupów, 1259 księży, 635 diakonów, 98 braci i 701 sióstr. Kościół liczy 469 parafii i 59 misji, i jest zorganizowany w siedem diecezji. Oprócz misji ewangelizacyjnej, Kościół ten jest zaangażowany w wychowanie oraz edukację dzieci i młodzieży, opiekę medyczną i działalność charytatywną.

W zakresie wychowania i edukacji Kościół katolicki prowadzi 3 seminaria, 4 uniwersytety, na których studiuje 29456 studentów, 37 szkół średnich, w których uczy się 24826 uczniów, 162 szkół podstawowych i 35 przedszkoli, do których uczęszcza 60901 uczniów i przedszkolaków, prowadzi 6 szkół specjalnych dla 664 uczniów, zatrudnia 7309 nauczycieli i pracowników administracyjnych. W katechezie pozaszkolnej (na Florydzie nie ma lekcji religii w szkole) uczestniczy 108319 uczniów. Katolicka opieka medyczna obejmuje 16 szpitali intensywnej opieki, 9 zakładów pielęgniarskich i inne usługi medyczne. Katolicka opieka społeczna to 252350 jednorazowych usług socjalnych rocznie, 31103 usług rodzinnego bezpieczeństwa ekonomicznego, 12776 usług mieszkaniowych, 1792894 usług żywnościowych oraz 21546 usług dla imigrantów i uchodźców.

Przytoczone dane wskazują, jak wiele poważnych zadań prowadzi Kościół na Florydzie i jak pilna jest konieczność sprawnego nim zarządzania. Koncepcja włodarzowania wychodzi naprzeciw tym potrzebom.

\section{Katolicka Społeczność Królowej Pokoju}

Już na pierwszy rzut oka zauważa się, że parafie Kościoła katolickiego na Florydzie, które miałem okazję odwiedzić ( 6 parafii z różnych diecezji), starają się budować dla siebie solidną infrastrukturę materialną, przekształcając się w nowoczesne i mocne ekonomiczne centra religijno-społeczne, oparte na zasadach ewangelicznych.

Silna ekonomicznie parafia jest w stanie wypełniać więcej zadań związanych z religijną i społeczną misją Kościoła. Koncepcja Kościoła ubogiego nie oznacza, że on sam jako instytucja ma być materialnie ubogi. System włodarstwa zachęca do realizacji coraz to większych zadań, a także do pomocy ubogim, na co potrzebne są coraz większe środki. Przytoczona wcześniej statystyka zakresu działań ewangelizacyjnych i społecznych, którą rokrocznie realizuje Kościół na Florydzie, wskazuje, że są potrzebne na nie wielkie środki. Realizacja tych zadań nie jest i nie może być bramą do bogacenia się jednostek, choć niektóre prace kościelne muszą być godnie opłacone.

Queen of Peace Catholic Church w Gainesville to nie tylko parafia, centrum katolickie i jej dobrze wyposażona, nowoczesna szkoła średnia, lecz przede wszystkim nadzwyczajna społeczność, która jest dumna z tego, że 


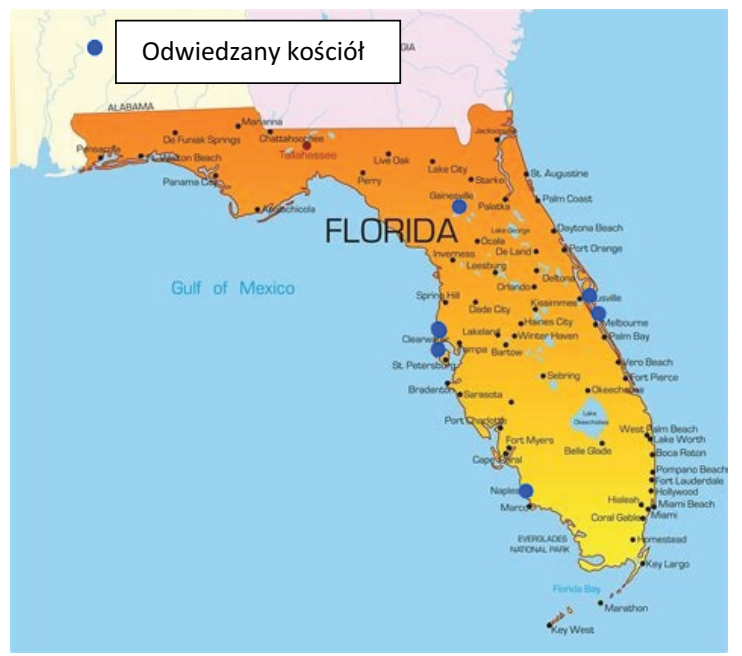

Ryc. 1. Mapa Florydy z lokalizacją i datami odwiedzin kościołów katolickich przez autora w drugiej połowie 2017 roku i na przełomie lat 2018 i 2019

1. 4.07.2017-3.01.2018 i 15.11.2018-21.01.2019 Queen of Peace Catholic Community Gainesville

2. 23.09.2017 St. Leo Church - Bonita Spring

3. 23.09.2017 St. James Apostolic Catholic Church - Port Richy (Tampa)

4. 15.10.2017 St. Teresa Catholic Church - Tytusville

5. 5.11.2017 Church of Our Saviour - Cocoa Beach

6. 25.11.201 Church of St. Brendan-Clear Water

żyje w Kościele i dla Kościoła. Amerykanie, chyba bardziej niż Polacy, czerpią satysfakcję z dumy i dlatego poszukują okazji, aby podkreślić swoją dumę z przynależności społecznej do rodziny, szkoły, Kościoła, państwa. Nie dostrzega się tu roszczeniowej postawy wiernych w stosunku do parafii, a raczej widać troskę o jej los, co objawia się autentycznym i powszechnym zaangażowania parafian w system włodarstwa.

Goście parafii, tacy jak my, prawie natychmiast zauważają nadzwyczajność atmosfery w parafii, wszechstronną usłużność wśród wiernych oraz precyzyjne zorganizowanie parafii na wszystkich polach jej działania. Będąc jeszcze w Gainesville, te pozytywy przypisywałem nadzwyczajnej charyzmie i zdolnościom organizacyjnej ówczesnego proboszcza parafii, otwartości wiernych na sprawy ludzi i Kościoła, a także szczęśliwemu trafowi, jaki się nam przydarzył w wyborze tymczasowej dla nas parafii. Pogląd ten stopniowo weryfikowałem. Odwiedzając inne parafie na Florydzie, zauważałem w nich podobne rozwiązania. Pomyślałem wówczas, że dobre praktyki zarządzania parafią szybko i spontanicznie na Florydzie się upowszechniają. Nie negując 
powyższego osądu, dopiero $\mathrm{w}$ Polsce - $\mathrm{i}$ to po przestudiowaniu wielu parafialnych i diecezjalnych stron internetowych - stwierdziłem, że dobre rozwiązania są efektem realizacji w Kościele amerykańskim koncepcji włodarstwa (stewardship). W cotygodniowym biuletynie parafialnym, nazwanym „Good News Bulletin", znajdujemy informację, że Queen of Peace Catholic Church jest parafią stosującą zasady włodarzowania we wszystkich obszarach jej działalności, co określa się tam terminem totalne włodarzowanie parafią (Total Stewardship Parish).

$\mathrm{Na}$ internetowej stronie tej parafii czytamy:

Nasza społeczność przyjęła włodarstwo totalne (total stewardship) jako swój sposób życia. W odpowiedzi na sugestie parafian, nasze podejście do edukacji w zakresie włodarstwa zostało zrewidowane i ustanowiono jego cztery obszary: włodarstwo czasu, włodarstwo talentów, włodarstwo skarbów i celebracja totalnego włodarstwa. Celem tych czterech obszarów jest podkreślenie ciągłości cyklu zarządzania. „Włodarzowanie jako sposób życia” nie oznacza tylko niedziel lub tylko ofiar z naszych pieniędzy. Włodarstwo jako droga życia wymaga, abyśmy umieścili Jezusa Chrystusa na pierwszym miejscu w naszym życiu i przeżywali każdy aspekt życia dla Jego chwały. Wymaga to od nas ofiary z naszego czasu, talentu i majątku. Ofiarowanie tylko jednego lub dwóch rodzajów darów sprawia, że nie jesteśmy pełni. Tylko dawanie całego siebie może doprowadzić człowieka do zrozumienia łaskawości i miłosierdzia Pana (Queen of Peace Catholic Community 2019).

\section{Filary i obszary włodarstwa w parafii katolickiej Królowej Pokoju w Gainesville}

Na stronie internetowej parafii czytamy: „Każda parafia jest unikalna, lecz dynamiczne parafie mają wiele wspólnych kluczowych elementów. U Królowej Pokoju gościnność, modlitwę, formację i posługę nazwaliśmy czterema filarami parafialnego włodarzowania" (Queen of Peace Catholic Community 2019).

\section{Gościnność - chrześcijańska uprzejmość}

„Bo byłem przybyszem, a przyjęliście mnie” (Mt 25,35). Jezus naucza, że jeżeli kiedykolwiek przyjmujemy najmniejszego z naszych braci lub sióstr, przyjmujemy samego Chrystusa. To wyjaśnia, dlaczego pierwszą oznaką parafialnego włodarstwa jest gościnność. Zwykła uprzejmość może sprawić, że inni będą nas uważać za podobnych do Chrystusa. 


\section{Modlitwa - w górę serca}

Modlitwa przygotowuje nas do wykonania rzeczy, o których nawet nie myślimy, że są możliwe, do zdobywania nowych szczytów, do czynienia woli Bożej. Czy jesteś usatysfakcjonowany ze swojego modlitewnego życia? Czy twoja rodzina regularnie modli się wspólnie? Czy Bóg wzywa ciebie do dłuższego spędzenia z nim czasu? Wsłuchuj się w swoje serce i zachęcaj siebie oraz swoją rodzinę do życia coraz bardziej ukierunkowanego na Chrystusa.

\section{Formacja - nieustanne nawracanie się}

Święty Jan Paweł II zawsze naciskał na nieustanne nawracanie się. Od dzieciństwa przez życie dorosłe całe nasze życie musi być procesem nieustannego przybliżania się do Boga. On nigdy nie przestaje wzywać nas, abyśmy się uczyli więcej i oceniali siebie coraz rzetelniej. U Królowej Pokoju mamy szczęście korzystać z licznych możliwości formacji przez całe życie i duchowego ubogacania się, które są wyszczególnione na Karcie Przymierza.

\section{Posługa - miłość w działaniu}

„Dałem wam bowiem przykład, abyście i wy tak czynili, jak Ja wam uczyniłem” (J 13,15). Były to słowa Chrystusa po umyciu stóp swoim apostołom w czasie ostatniej wieczerzy. W tym dramatycznym momencie wezwał On swoich naśladowców do życia w pokorze i do służenia. Pomaganie innym, szczególnie biednym, jest tym, czym nasza wspólnota parafialna wypełnia Chrystusowe przykazanie: „Kochaj bliźniego jak siebie samego” (Mt 19,19).

Powszechnie w parafiach wyróżnia się ponadto trzy pola włodarzowania: modlitwę, posługę i finanse.

\section{Potrzeba dzielenia się darami z innymi}

Jedną z ważnych potrzeb człowieka, która jest kluczowym elementem koncepcji włodarstwa, jest potrzeba dzielenia się (the need to give) tym, co człowiek otrzymał jako dar od Boga. Człowiek ma potrzebę dzielenia się z innymi swoim czasem (time), umiejętnościami (talents) i majątkiem (treasure). Kościół naucza, że te dary (dobra) nie są bezwzględną własnością człowieka, lecz otrzymuje on je czasowo od Boga po to, aby je odpowiedzialnie rozwijać i z nich korzystać, dzielić się nimi z innymi, a w końcu, pomnożone, oddać je 
ich właścicielowi - Bogu. Amerykańska Konferencja Biskupów Katolickich, w liście pasterskim Włodarzowanie jako odpowiedź ucznia, tak definiuje jego istotę: „Jako chrześcijańscy włodarze $\mathrm{z}$ wdzięcznością przyjmujemy Boże dary, odpowiedzialnie je rozwijamy, z miłością i w sprawiedliwości dzielimy się nimi z innymi, a pomnożone zwracamy Panu" (United States Conference of Catholic Bishops 2002, s. 42) ${ }^{2}$.

Powyższe słowa dotyczące chrześcijańskich włodarzy nadzwyczaj dobrze współbrzmią z przypowieścią o talentach z Ewangelii według św. Mateusza (Mt 25,14-30).

\section{Karta przymierza - Covenant Card}

Człowiek czasami może mieć trudności nie tyko z rozpoznaniem darów, które otrzymał od Boga, lecz także ze znalezieniem sposobu dzielenia się nimi z innymi oraz ich pomnażania. Trzeba tej trudności zaradzić. Tymczasem każdy rządca parafii potrzebuje do realizacji zadań parafialnych wielu współpracowników. Często zdarza się niestety tak, że rządca nawet nie wie, iż wielu parafian $\mathrm{z}$ radością przyjęłoby jego prośbę o konkretną pomoc. Mamy więc $\mathrm{z}$ jednej strony do czynienia $\mathrm{z}$ oczekiwaniami potrzebującego, a z drugiej dającego, które potencjalnie mogą być, ale - z braku o sobie wiedzy - nie są spełnione. Jest to bardzo frustrująca sytuacja. Queen of Peace Catholic Society rozwiązuje ten problem poprzez Karte Przymierza (Covenant Card). Karta Przymierza jest to deklaracja darów: czasu, umiejętności i majątku, które włodarz dobrowolnie zamierza przekazać lub już przekazuje na rzecz innych osób, nie tylko z parafii. Deklaracje do Karty Przymierza w Queen of Peace Catholic Society najpierw zebrano w formie ankiety papierowej, a w chwili obecnej dostępna jest ona w formie elektronicznej na stronie internetowej parafii. W czasie naszego pobytu w tej parafii każdemu uczestnikowi niedzielnej Mszy św. wręczono ankietę. Jej celem było poznanie darów, którymi parafianie już się dzielą lub zamierzają się w przyszłości dzielić z innymi. Lista pytań daje imponujący obraz modlitewnej oferty parafii, bogactwa grup duszpasterskich i ich posługi oraz pokazuje możliwe sposoby finansowania parafii przez wiernych. Ankietę wypełniają tylko chętni. Za celowe uznałem zamieszczenie w niniejszym opracowaniu polskiego thumaczenia tej ankiety (II edycja ankiety z 2019 toku), ponieważ może służyć za wzorzec dla zainteresowanych w Polsce. W kwadraciku $\square$ przy pytaniu zaznacza się swoje obecne zaangażowanie, w kółku $\bigcirc$ - zainteresowania, a na linii __ wpisuje się imię członka

${ }^{2}$ „As Christians stewards, we receive God's gifts gratefully, cultivate them responsibly, share them lovingly in justice with others, and return them with increase to the Lord". 
rodziny. Ankieta nie jest anonimowa i dotyczy całej rodziny. Respondenci są proszeni o podanie swoich danych teleadresowych. W warunkach polskich potrzebna jest pisemna zgoda na przetwarzanie danych. Ankieta obejmuje cztery sekcje: 1) dane imienne i teleadresowe, podpisane przez respondenta, 2) czas, 3) talenty, 4) skarbiec. W ankiecie wymieniono aż 62 rodzaje dostępnych posług w Queen of Peace Catholic Community, które umożliwiają dzielenie się z innymi otrzymanymi od Boga darami. Są to posługi: modlitewne, formacyjne, gościnności, usługowe i liturgiczne. Posługi te są najczęściej pełnione w grupach duszpasterskich, a także indywidualnie. Nazwy większości posług odzwierciedlają ich zakres kompetencji, chociaż niewtajemniczonym niewiele mówią. Na przykład, grupa Alfa jest ośmiotygodniowym programem opracowanym w celu odpowiedzi zainteresowanym na najważniejsze życiowe pytania, które są losowo wybrane i nie ma tutaj znaczenia, czy są one bardzo skomplikowane, czy też proste. Aby zaradzić brakowi wtajemniczenia, parafia wydała specjalny informator charakteryzujący w kilku zdaniach poszczególne posługi. W poniższej ankiecie nazwy posług, które niewiele mówią o nich samych, pozostawiono w wersji oryginalnej, utrzymano ich alfabetyczną angielską sekwencję.

\section{Ile na ofiarę?}

Jest to zawsze delikatne i trudne pytanie, które zadają sobie wierni na całym świecie. Potrzeby Kościoła są duże, a pieniędzy na różne szczytne cele stale brakuje. Widoczny jest wzrost hojności Amerykanów na przestrzeni ostatniego sześćdziesięciolecia, co opisano w dalszej części tego artykułu. Wierni chętnie wspierają umotywowane potrzeby Kościoła, a ci, którzy kierują się zasadami włodarzowania, są nawet bardziej hojni.

Każde przedsięwzięcie, w tym także w parafii, wymaga płynnego finansowania. Queen of Peace Catholic Community prowadzi bardzo szeroką działalność duszpasterską, która wymaga stałego i znacznego finansowania. Nic więc dziwnego, że w ankiecie znalazło się pytanie o wielkość, częstość i formę ofiary. Wierni powinni też wiedzieć, jaką część ze swoich dochodów przeznaczają na Kościół: czy jest to: 1\%, 2\%, czy więcej. Zwyczajowo, dochody Amerykanów wyraża się w stosunku rocznym, a nie miesięcznym. Jeżeli co tydzień Amerykanin ofiarowuje na rzecz Kościoła 10 USD, a jego roczny dochód wynosi 50000 USD, to oznacza, że ofiarowuje on 1\% rocznego dochodu. Zachęca się, aby włodarze byli bardziej hojni. 


\section{Ankieta}

\section{Czas (time) - spędzenie czasu na modlitwie z Bogiem}

Bóg obdarowuje każdego z nas i każdego tygodnia 168 godzinami, w uzupełnieniu do tygodniowych Mszy św. Ile dodatkowego czasu możesz przeznaczyć dla Pana Boga i w jaki sposób go spożytkujesz?

Uczestniczenie w każdą niedzielę i w każde święto we Mszy św.

$\square$ Uczestniczenie przynajmniej raz w tygodniu, w dniu powszednim, we Mszy św.

Przeznaczenie codziennie 15 minut na osobistą modlitwę

Adoracja przynajmniej przez jedną godzinę tygodniowo w Kaplicy Wieczystej Adoracji

Wspólna modlitwa z moimi najbliższymi

Czytanie Pisma Świętego przynajmniej godzinę tygodniowo

$\square$ Modlitwa różańcowa przynajmniej raz w tygodniu

Comiesięczna spowiedź

$\square$ Zapewnienie czasu na kontemplację (osobista refleksję)

$\square$ Uczestnictwo w kręgu (studium) biblijnym

\section{Talenty (talents) - wykorzystanie moich talentów w posłudze parafialnej}

W jaki sposób możesz wykorzystać twoje, lecz otrzymane od Boga, zdolności, pasje i doświadczenie życiowe, aby podzielić się Bożą miłością z innymi?

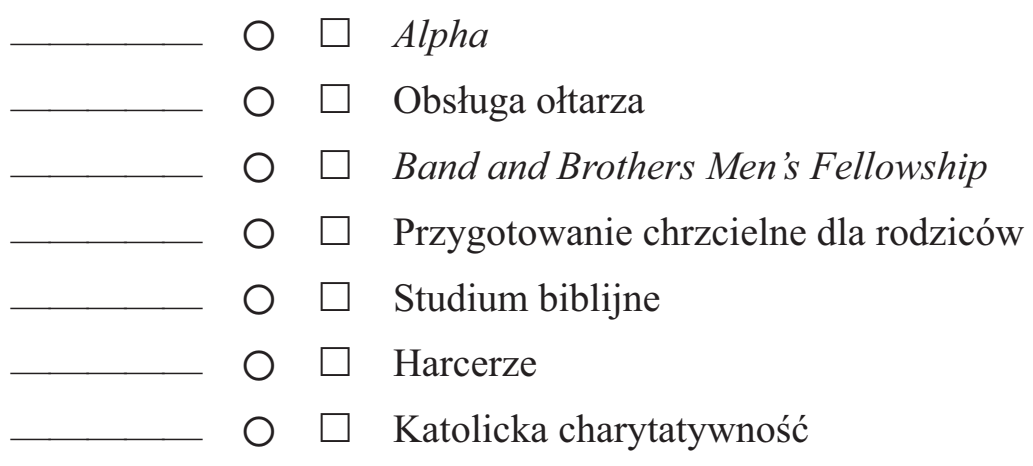


$\bigcirc \quad \square \quad$ Przygotowanie do bierzmowania (10 klasa)

$\bigcirc \quad \square$ Przygotowanie dorosłych do bierzmowania

$\bigcirc \quad \square$ Posługa pocieszenia

$\bigcirc \quad \square \quad$ Pomoc pielęgniarska

○ $\square$ Pomocna dłoń

$\bigcirc \quad \square$ Adoracja eucharystyczna i nabożeństwa

$\bigcirc \quad \square$ Eucharystyczni szafarze

$\bigcirc \quad \square \quad$ Formacja wiary

$\bigcirc \quad \square \quad$ Family promise

$\bigcirc \quad \square$ Organizacja pogrzebów

$\bigcirc \quad \square$ Przyjęcia pogrzebowe (stypy)

$\bigcirc \quad \square$ Harcerki

$\bigcirc \quad \square \quad$ Złote Aligatory

$\bigcirc \quad \square \quad$ Greeters \& and Gift Bearers

$\bigcirc \quad \square \quad$ Modlitwy o uzdrowienie

$\bigcirc \square$ Gościna (agapa, poczęstunek) po Mszy św.

$\bigcirc \quad \square$ Posługa informacyjna

$\bigcirc \quad \square \quad$ My Młodzi Duchem

$\bigcirc \quad \square \quad$ Rycerze Kolumba

$\bigcirc \quad \square \quad$ Lądowanie; powracający katolicy

$\bigcirc \quad \square \quad$ Lektorzy

$\bigcirc \quad \square \quad$ Sztuka liturgiczna i środowisko?

$\bigcirc \square$ Technologia liturgiczna

$\bigcirc \quad \square$ Grupa modlitewna Słowa Żywego

$\bigcirc \quad \square \quad$ Living Your Strengths

$\bigcirc \quad \square$ Medyczna Posługa dla Haiti

$\bigcirc \quad \square \quad$ Małżeńskie i narzeczeńskie pary

$\bigcirc \quad \square \quad$ Ministry of Mothers Sharing

$\bigcirc \quad \square$ Posługa wielokulturowa 


\section{Posługi muzyczne}

$\bigcirc \quad \square$ Chór Cherubów

$\bigcirc \square$ Chór pogrzebowy „Zmartwychwstanie”

$\bigcirc \quad \square \quad$ Chór Ręczne Dzwonki

$\bigcirc \quad \square$ Weekendowy Chór Instrumentalny

$\bigcirc \square$ Aniołki, młodzieżowy chór i orkiestra (3-8 klasa)

$\bigcirc \quad \square$ Powitanie nowych parafian

$\bigcirc \square$ Zespół biurowy

○ $\square$ Październikowy festiwal

$\bigcirc \quad \square \quad$ Linia modlitewna

$\bigcirc \quad \square$ Wolontariat dla Akademii Królowej Pokoju

$\bigcirc \quad \square$ Obrzędy Chrześcijańskiej Inicjacji dla Dorosłych (RCIA)

$\bigcirc \quad \square$ Obrzędy Chrześcijańskiej Inicjacji dla Młodzieży (RCIA)

○ $\square$ Droga Pełnego Życia (RAL)

$\bigcirc \quad$ Zakrystianin

$\bigcirc \quad \square$ Sklep pamiątkarski im. św. Antoniego

$\bigcirc \square$ Scrapbooking with Faith

$\bigcirc \quad \square$ Nadzwyczajne wydarzenia

$\bigcirc \quad \square$ Sportowa posługa dla starszych (kręgle)

$\bigcirc \square$ Ushers

○ $\square$ Posługa Eucharystyczna w domu chorego

$\bigcirc \quad \square \quad$ Małe uwielbienie

$\bigcirc \quad \square \quad$ Wild Women of Faith (Zelatorki)

$\bigcirc \quad \square$ Posługa starszej młodzieży

$\bigcirc \quad \square \quad$ Posługa młodzieży

$\bigcirc \square$ Grupa Elevae

○ $\square$ Grupa Pathfinders

$\bigcirc \quad \square$ Grupa Peer Ministes

$\bigcirc \quad \square$ Grupa Visions 


\section{Skarb (treasure) - składanie Bogu szczodrego daru}

Dar czasu i zdolności wykorzystujemy w celu wytworzenia owoców ziemi. W jaki sposób możemy Bogu ofiarować jej pierwsze owoce jako wyraz podziękowania za jego wielką miłość? Mój dar na ofiarowanie - to deklaracja ofiar, które mają być przeznaczone jako ten dar. Parafianie wpisują kwotę, którą chcą ofiarować na potrzeby parafii, oraz częstotliwość, z jaką zamierzają ją przekazywać: tydzień, miesiąc, rok, a także sposób jej przekazania:

$\square$ Podpiszę datki elektroniczne

Chciałbym ofiarować datek z naszego majątku

Chciałbym włączyć QOP (Queen of Peace) w mój testament

Biblia ukazuje dziesięcinę jako Boży zamiar odnośnie do naszych finansów, które budują jego królestwo. Wspieramy misję Chrystusa, która jest naszą misją, z pierwszych $10 \%$ naszych dochodów. Ty także możesz dążyć w kierunku osiągnięcia biblijnej dziesięciny wskutek zwiększenia twojej ofiary o $1 \%$ lub $2 \%$.

\begin{tabular}{|c|c|c|c|c|}
\hline \multirow{2}{*}{$\begin{array}{l}\text { Roczny dochód } \\
\text { gospodarstwa } \\
\text { domowego }\end{array}$} & $10 \%$ & $8 \%$ & $5 \%$ & $1 \%$ \\
\hline & \multicolumn{4}{|c|}{ Wysokość tygodniowej ofiary } \\
\hline$\$ 10000$ & $\$ 20$ & $\$ 15$ & $\$ 10$ & $\$ 2$ \\
\hline$\$ 20000$ & $\$ 38$ & $\$ 31$ & $\$ 19$ & $\$ 4$ \\
\hline$\$ 30000$ & $\$ 58$ & $\$ 46$ & $\$ 29$ & $\$ 6$ \\
\hline$\$ 50000$ & $\$ 96$ & $\$ 77$ & $\$ 48$ & $\$ 10$ \\
\hline$\$ 75000$ & $\$ 144$ & $\$ 115$ & $\$ 72$ & $\$ 14$ \\
\hline$\$ 100000$ & $\$ 192$ & $\$ 154$ & $\$ 96$ & $\$ 20$ \\
\hline$\$ 200000$ & $\$ 384$ & $\$ 308$ & $\$ 292$ & $\$ 30$ \\
\hline
\end{tabular}

U Królowej Pokoju nie mamy drugiej tacy ani zbiórek pieniędzy, loterii, gier hazardowych czy zabaw płatnych. Włodarzowanie czyni wszystko możliwym.

\section{Owoce włodarzowania}

Nie sposób w niniejszym artykule przedstawić całego bogactwa plonów uzyskiwanych w wyniku realizacji w parafii Queen of Peace Catholic Church 
w Gainesville koncepcji całkowitego nią włodarzowania (total stewardship parish), czyli we wszystkich aspektach jej funkcjonowania. Dlatego ograniczę się do omówienia pięciu jego elementów, które jako goście tej parafii - nie znając jeszcze wtedy koncepcji włodarstwa - najszybciej zaważyliśmy. Omówimy więc: (1) parafialny system informacji, (2) organizację niedzielnej Mszy św. połączonej z agapą, (3) tacę w formie elektronicznej ofiary, (4) koordynację działań włodarzy w celu zapewnienie płynnej realizacji parafialnych uroczystości i innych przedsięwzięć.

\section{Parafialny system informacyjny}

To prawdziwa rewolucja informatyczna w tej parafii. Pomimo że obejmuje wiele kanałów informacyjnych, w tym: parafialną stronę internetową i stronę społecznościową na Facebooku, cotygodniowy parafialny biuletyn (,Good News Bulletin") zarówno w wersji papierowej, jak i elektronicznej, parafialny miesięcznik, kalendarz, serię tematycznych stale dostępnych ulotek, plakaty i ustne przekazy informacyjne oraz system parafialnych e-maili (nie korzysta się z e-maili prywatnych w sprawach parafialnych), funkcjonuje perfekcyjnie. System ten pozwolił faktycznie wyeliminować ustne ogłoszenia parafialne, a potrzebny na nie czas przeznacza się na liturgię. Czasami podczas niedzielnej Mszy św. celebrans podaje ważny, króciutki komunikat, przez co istotnie wzmacnia się skuteczność tej informacji. Ważne ogłoszenia są także specjalnie przekazywane przez wiernych. Dzięki takiemu systemowi, każda informacja jest przynajmniej raz odebrana przez każdego parafianina. Wielość kanałów informacyjnych istotnie wzmacnia przekaz. Biuletyn parafialny co tydzień jest wręczany parafianom opuszczającym kościół po niedzielnej Mszy św. Porównując biuletyny różnych parafii, łatwo zauważyć, że część informacji musi być przygotowywana na poziomie Kościoła USA lub diecezji, a pozostała część na poziomie parafii. Dzięki temu informacje przekazywane wiernym są dobrej jakości i nie ma „wpadek”, choćby związanych z naruszaniem prawa autorskiego. Dostarczana informacja jest stale aktualizowana, a zamieszczanie jej w sieci pozwala obniżyć koszty jej powstawania. Cotygodniowy biuletyn zapewne jest finansowany przez związanych z parafią przedsiębiorców, którzy zamieszczają w nim reklamy swojej działalności gospodarczej na zasadzie niedrogiego abonamentu. Reklamy zajmują około $50 \%$ objętości biuletynu. Strona internetowa parafii jest bardzo przyjazna w odbiorze. Nie jest nudnym zestawem mało przydatnych dywagacji, lecz jest bardzo praktycznym i pożytecznym narzędziem pracy dla każdego użytkownika. Na uwagę zasługuje zakładka Formularze do pobrania, ułatwiająca załatwienie spraw służbowych, która jest elektronicznym biurem parafialnym. 


\section{Celebracja niedzielnych i świątecznych Mszy Świętych}

W niedziele i święta celebruje się w Queen of Peace cztery Msze św. $\mathrm{w}$ języku angielskim i jedną w hiszpańskim, $\mathrm{z}$ dużym udziałem wiernych, a w szczególności dzieci. We Mszy św. o godz. 10.00 uczestniczy od 600 do nawet 1000 wiernych. Parafia - to tygiel narodowościowy, którego lepiszczem jest wspólnota wiary. Według mojego szacunku, rasowa i narodowościowa struktura wiernych uczestniczących we Mszy św. jest następująca: biali $50 \%$, Latynosi - 20\%, Afroamerykanie i czarni - 10\%, Azjaci (głównie Filipińczycy) - 10\% i inni - 10\%.

Budynek świątyni, jego wyposażenie i wystrój oraz oprawa liturgiczna są najlepszej jakości. Układ świątyni jest amfiteatralny. „Nasza” niedzielna Msza św. o godz. 10.00 i następująca po niej agapa to poważne cotygodniowe przedsięwzięcia logistyczne, w których posługę jest zaangażowanych co najmniej 100 osób. W tej liczbie są: celebrans, ministranci, lektorzy i psalmiści, kolektorzy, piloci wskazujący księdzu niepełnosprawnych przyjmujących Komunię św., szafarze nadzwyczajni, osoby kierujące strumieniem wiernych przystępujących do Komunii św., dystrybutorzy cotygodniowej gazetki parafialnej, orkiestra, chór, obsługa techniczna nagłośnienia, multimedium i oświetlenia. Do tego należy dodać osoby obsługujące agapę po Mszy św. i obsługę sklepiku parafialnego z dewocjonaliami. Każdej osobie zaangażowanej w posługę przypisana jest precyzyjnie rola.

Sredni czas trwania niedzielnej Mszy św. to 1 godz. 5 minut z wahaniami od 55 minut do 1 godz. i 15 minut. Po Mszy św. odbywa się agapa, typu raut, gromadząca na około 30-45 minut wiernych, w czasie której ogólnodostępne są: kawa, herbata, soki i wypieki domowe (małe pączki). Często raut ma temat wiodący, na przykład: dzień polski, filipiński, puertorikański czy włoski.

Na podkreślenie zasługuje bardzo dobre wykorzystanie multimedium podczas całej Mszy św.; chór wspaniale współpracuje z wiernymi. W czasie liturgii słowa zarówno celebrans, jak i ministranci zajmują mało wyeksponowane miejsce z prawej strony prezbiterium, nie przysłaniając swoją osobą tabernakulum, a w czasie kazania ministranci siedzą w pierwszej ławce. Ołtarz jest $\mathrm{w}$ zasadzie pusty z wyjątkiem przeistoczenia. Gestykulacja wiernych jest bogata. Wierni w czasie Mszy św. przyjmują pozycję stojącą, siedzącą i klęczącą (z przewagą czasową dla pozycji siedzącej, potem klęczącej, a na końcu stojącej). Po słowach: „Módlcie się bracia, aby moją ofiarę [...]”- wierni zwracają się do sąsiada z prośbą o modlitwę w konkretnej intencji. W czasie Ojcze nasz wierni trzymają się za dłonie, które unoszą nieco wyżej na słowa: „Bo Twoje jest królestwo [...]. Po słowach: „Przekażcie sobie znak pokoju” - gesty są okazałe, spontaniczne, ale cieple i braterskie. Komunia św. jest udzielana pod dwoma postaciami. Procesja do komunii jest kierowana i uporządkowana. 
Na specjalne podkreślenie zasługuje obrzęd chrztu. Ochrzczone dziecko jest pokazywane wiernym, a ci z radosnymi oklaskami witają je w parafialnej społeczności. Na zakończenie Mszy św. zwykle jest udzielane błogosławieństwo z okazji jubileuszów lub innych okazji. Celebrans wzywa, aby się ujawniały poszczególne grupy jubilatów, po czym wszyscy wierni kierują pochyloną rękę w ich kierunku i modlą się w wraz z celebransem w ich intencji. Na przykład, w dniu weterana modlono się kolejno za weteranów wojny koreańskiej ( 2 osoby wstały), wietnamskiej (3 osoby), afgańskiej ( 2 osoby), w Zatoce Perskiej (4 osoby).

Na ogół celebrans nie odczytuje ogłoszeń parafialnych, choć zdarzają się wyjątki. Powszechną praktyką w kościołach na Florydzie jest spokojne odśpiewanie w czasie Mszy św., razem z kapłanem, dwóch, a nawet trzech wielozwrotkowych pieśni. Teksty wszystkich czytań, psalmu responsoryjnego i pieśni są wyświetlane na dużych ekranach. Nierzadko kazanie jest wspomagane obrazami albo filmem.

\section{Elektroniczna taca}

Wielu parafian wybiera elektroniczne i automatyczne ofiarowanie niedzielnej tacy. W tym celu wykorzystuje się konto bankowe lub rachunek instytucji kredytowych. Na ogół elektroniczne przekazywanie pieniędzy jest zwolnione z opłat, zarówno dla Kościoła, jak i wpłacającego. Wpłaty są dokonywane według schematu ustalonego przez ofiarodawcę. Pieniądze wpłaca się poprzez odpowiednią zakładkę istniejącą na stronie internetowej parafii. Porównanie internetowego sposobu dokonywania wpłat w różnych parafiach wskazuje, że jest to rozwiązanie przygotowane na poziomie diecezji lub może nawet na poziomie całych Stanów Zjednoczonych Ameryki.

Efektowność elektronicznego systemu jest dobra, a wielkość datków ofiarowanych w ten sposób jest podawana do publicznej wiadomości. Na przykład, „Good News Bulletin” podał, że w weekend 10-11.02. 2018 roku zebrano 47676 USD, włączając w to 279 USD z ofiar przekazanych przez dzieci, w weekend 7-8.04.2018 roku - 45279 USD, wliczając w to 318 USD z ofiar przekazanych przez dzieci, 5-6.05.2018 roku - odpowiednio 58 453 USD i 712 USD, 3.03.2019 roku - 58484 i 362 USD, a poprzez platformę elektroniczną wypłynęło 17441 USD.

\section{Koordynacja działań włodarzy}

Koordynacja działań włodarzy ma na celu płynną realizację parafialnych uroczystości i innych przedsięwzięć. Parafia Królowej Pokoju w terminologii 
świeckiej jest bardzo znaczącą organizacją porównywalną z wielkimi przedsiębiorstwami. Szacuję, że związanych z nią jest przynajmniej 500 włodarzy i kilka tysięcy „zwykłych” wiernych. Koordynowanie działań tak dużej grupy ludzi wymaga nadzwyczajnych przedsięwzięć organizacyjnych. Okazało się, że w Parafii Królowej Pokoju wykorzystuje się program komputerowy Sign Up Genius, który ma specjalną opcję, ułatwiającą zarzadzanie kościelnym wolontariatem. Za jej pomocą zarząd parafii kontaktuje się z włodarzami danej posług. Miałem okazję zarówno zapoznania się z funkcjonowaniem, jak i z efektem zastosowania tej aplikacji na przykładzie uroczystości powitania nowego proboszcza omawianej parafii. Po rozpoznaniu potrzeb, lider grupy tworzy ich szczegółową listę oraz listę zadań, po czym wysyła je do osób zainteresowanych, oczekując na deklarację ich udziału w wybranym przedsięwzięciu.

\title{
STRESZCZENIE
}

Niniejszy artykuł jest refleksją profesora ekonomii nad sposobem zarządzania parafiami w Stanach Zjednoczonych Ameryki Północnej. Stanowi przyczynek do rozwoju nowoczesnej, katolickiej teorii ekonomii, zarządzania i finansów. Podstawę jej prezentacji stanowi zarysowana blisko 60 lat temu przez Konferencję Katolickich Biskupów Stanów Zjednoczonych koncepcja kościelnego włodarzowania (stewarship), która odwołuje się zarówno do Biblii, jak i do społecznego nauczania Kościoła. Jest to pewna teoria ekonomii, finansowania i zarządzania na poziomie parafii i diecezji. Istota jej polega na włączeniu w życie Kościoła tysięcy wolontariuszy zainspirowanych do działania opisaną tu koncepcją kościelnego włodarzowania. Jest to pierwsza część opracowania. Druga ukaże się w kolejnym tomie czasopisma.

Slowa kluczowe: Kościół; diecezja; parafia; dobra materialne; zarządzanie; włodarzowanie

\author{
STEWARDSHIP IN THE CATHOLIC CHURCH \\ OF THE UNITED STATES OF NORTH AMERICA
} (PART I)

\section{SUMMARY}

The paper is a reflection by a professor of economics on parish management in the United States of North America. It is meant as a contribution to the development of a modern Catholic theory of economics, management and finances. The presented 
considerations are based on the notion of Church stewardship which refers both to the Bible and the social teaching of the Church. It is a theory of economics, finances and management on the level of the parish and the diocese. Essentially, it consists in engaging thousands of volunteers in the life of the Church who are inspired in their activity by the aforementioned idea of Church stewardship. This is the first part of the study. The second part will appear in the next volume of the journal.

Keywords: Church; diocese; parish; material goods; management; stewardship

\section{BIBLIOGRAFIA}

Carlson J. (2010): Taking Stewardship Seriously. http://archstl.org/files/field-file/Archbishop's\%20 talk\%20-\%20final.pdf [dostęp: 10.04.2018].

Diakonijny Model Parafialnej Rady Duszpasterskiej jako fundament wspólnoty parafialnej. (2014). Poznań. http://propublico.org/pl/diakonie-w-parafii [dostęp: 14.01.2020].

Florida Conference of Catholic Bishops. (2018). https://flaccb.org/mission-and-vision [dostęp: 10.04.2018].

Franciszek (2015): Encyklika Laudato si'. https://w2.vatican.va/content/dam/francesco/pdf/encyclicals/documents/papa-francesco_20150524_enciclica-laudato-si_pl.pdf [dostęp: 10.04.2018].

Greek Orthodox Archidiocese of America Department of Stewardship. (2018). https://www.goarch. org/departments/stewardship [dostęp: 27.04.2018].

http://catholiclubbock.org/StewardshipADisciplesResponse.pdf [dostęp: 2.04.2018].

https://en.wikipedia.org/wiki/Stewardship [dostęp: 29.04.2018].

https://stewardshipresources.org/ [dostęp: 20.03.2018].

https://www.encyclopedia.com/religion/encyclopedias-almanacs-transcripts-and-maps/international-catholic-stewardship-council [dostęp: 27.04.2018].

Office of Stewardship Catholic Diocese of Baton Rouge. (2018). https://officeofstewardship.com/ [dostęp: 2.04.2018].

Philanthropy Roundtable Statistics. (2018). http://www.philanthropyroundtable.org/almanac/statistics/ [dostęp: 20.05.2018].

Pismo Święte Starego i Nowego Testamentu (Biblia Tysiąclecia). http://biblia.deon.pl/szukaj.php [dostęp: 10.04.2018].

Queen of Peace Catholic Community. (2018). http://www.queenofpeaceparish.org/ [dostęp: 16.04.2018 i 15.03.2019].

Queen of Peace Catholic Community. (2019): Covenant Card.

Queen of Peace Catholic Community (2019): Ministry Guidebook.

Roman Catholic Diocese of Worcester (2018): Is Your Parish Ready for Stewardship. https://worcesterdiocese.org [dostęp: 18.05.2018].

The Archdiocese of Winnipeg. Office of Stewardship (2011): Catholic Stewardship Rooted in Scripture \& Church Teaching. http://www.archwinnipeg.ca/docs/Stewardship\%20in\%20Scriptures\%20Church\%20Teaching.pdf [dostęp: 30.04.2018].

U.S. Religion Census from 1952 to 2010 Maps and Charts for 2000. http://www.usreligioncensus. org/ [dostęp:16.05.2018].

United States Censcus Bureau Powerty. (2018). https://www.census.gov/topics/income-poverty/ poverty.html [dostęp: 13.05.2018].

United States Census Bureau. Quick Facts - Florida. (2018). https://www.census.gov/quickfacts/FL [dostęp: 10.04.2018]. 
United States Conference of Catholic Bishops. Stewardship A Disciple's Response (2002): A pastoral Letter on Stewardship. Tenth Anniversary Edition. Washington DC.

Williams B.D. (2018): An Orthodox Understanding of Stewardship [dostęp: 27.04.2018].

Michat JACENTY SzNAJDER: emerytowany profesor zwyczajny nauk ekonomicznych Uniwersytetu Przyrodniczego w Poznaniu; e-mail: michal.sznajder@ horyzont.biz. 